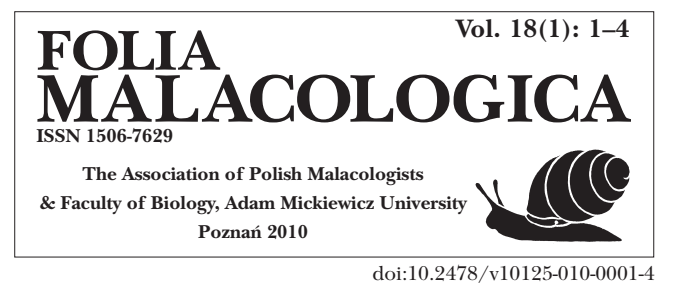

\title{
ELŻBIETA KORALEWSKA-BATURA (1949-2008)
}

\section{OBITUARY}

Our colleague and friend, Professor Elżbieta Koralewska-Batura, died on September 12th 2008 in Poznań after a long illness, at the age of 59. Elżbieta was a well-known and valued malacologist, and a staff member of the Faculty of Biology, Adam Mickiewicz University. Besides malacology, her research interests included biology teaching. She was buried in Poznań, at the parish cemetery, Jasna Rola Street. On the first anniversary of her death we would like to commemorate her, and recall her main achievements as a malacologist and as a teacher.

Elżbieta Koralewska-Batura was born on the 12th of May 1949 in Pyzdry, Września district (Wielkopolska voivodeship). Having finished elementary school, she continued her education at the Pedagogical High School in Konin. After her school leaving exam she spent half a year working as a teacher in an elementary school. In 1969 Elżbieta started her biological studies at the Faculty of Biology and Earth Sciences, Adam Mickiewicz University in Poznań. During all her study period she was an outstanding student. In 1974 she obtained her master's degree in biology (zoology), with top grades. The title of Elżbieta's master's thesis was "Ślimaki (Gastropoda) lądowe i wodne Ziemi Wrzesińskiej” [Terrestrial and freshwater gastropods of the Września Region]; the thesis was prepared at the Department of General Zoology and supervised by the outstanding malacologist Professor Jarosław Urbański. Immediately after getting her degree, Elżbieta became employed as biology teacher at the College for Nursery School Teachers in Sulechów.

On September 1st 1975 Elżbieta became employed as an academic teacher - scientific assistant at the Department of General Zoology, Institute of Biology, Adam Mickiewicz University. At that time she married Mr. Ryszard Batura, M. Sc., Eng., a scientist from Poznań Technical University, and gave birth to a son.

During all her professional life, Elżbieta dealt with malacology and biology teaching, being a very trustworthy and scrupulous worker, much valued by her colleagues. Her malacological studies were mainly of

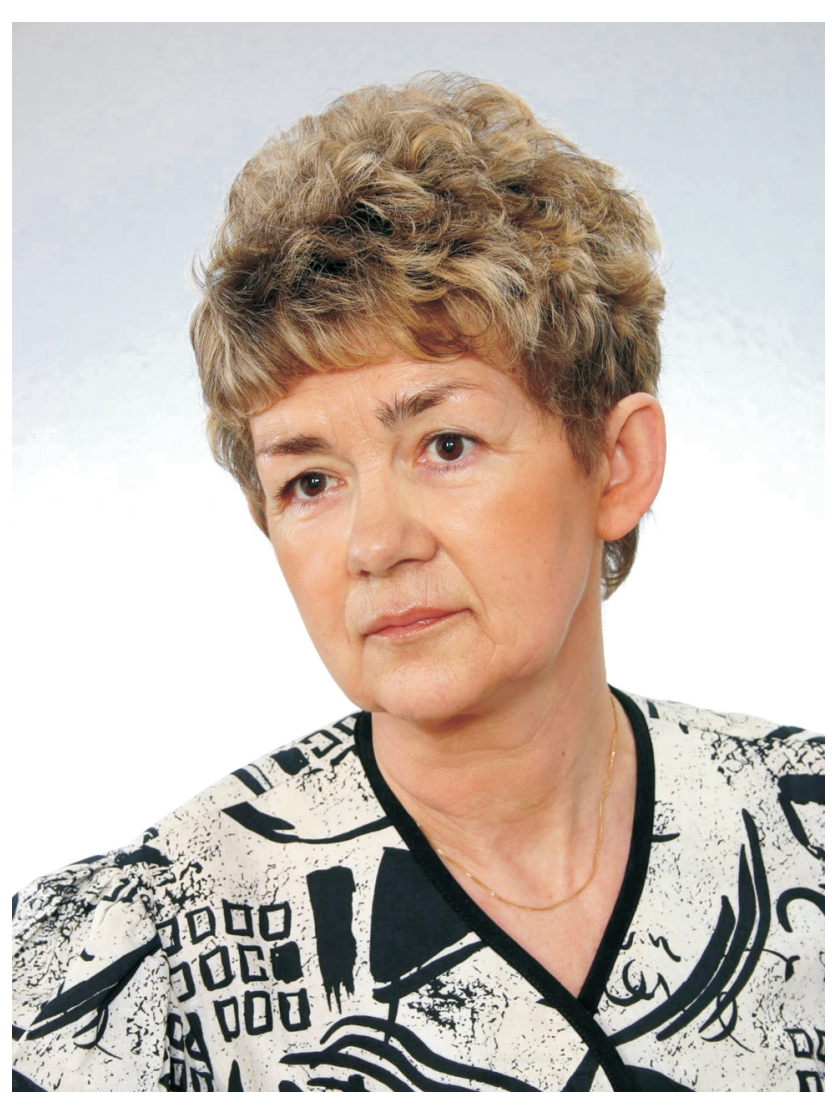

faunistic-ecological and morpho-anatomical character. She worked first under supervision of and then in cooperation with the outstanding specialist in mollusc anatomy, Professor Maria Jackiewicz. She took part in interdisciplinary field studies on the fauna of oak-hornbeam forests of western Wielkopolska, where she surveyed the terrestrial malacocoenoses. As a teacher Elżbieta was much appreciated by her students. At the same time she cooperated with schools (within biology teaching), and since 1994 was responsible for organising field courses for students of the Faculty of Biology.

Elżbieta Koralewska-Batura got her doctor's degree within zoology on the 20th February 1984; her 
thesis was "Mięczaki (Mollusca) Wielkopolski" [Molluscs of Wielkopolska], supervised by Professor Kazimierz Stępczak. The results were published under the same title in 1992. Regional studies on the malacofauna of Wielkopolska were very important for Elżbieta from the very start. Creating the unique computer database with all the available (published and unpublished) information on the molluscs of Wielkopolska was her idea. These studies were later to form the basis for a cycle of publications on the state of knowledge of the malacofauna of the region.

Another field in which Elżbieta was an unquestionable authority was snail anatomy. The long lasting cooperation with Professor Maria Jackiewicz in this respect brought numerous publications on the anatomy of various snail specis, published in widely recognised Polish and international scientific journals. Elżbieta obtained her degree of habilitated doctor on the 21st of June 2000, based on the monograph "Helix lutescens Rossmässler, 1837 (Gastropoda: Pulmonata: Helicidae) - its structure, biology and ecology", in which her own original anatomical studies and observations on circadian and seasonal activity as well as mating behaviour and reproduction formed a very valuable part. This was well illustrated by a fragment of Professor Jackiewicz's review of the thesis: "Monographs devoted to individual species are very rare in malacological literature. Their preparation is extremely time-consuming. The publication of Dr. Elżbieta Koralewska-Batrura is a very valuable, comprehensive monograph of an otherwise rather poorly studied species (Helix lutescens). The original data contained in it pertain to morphology, anatomy, histology, as well as biology and ecology. Some illustrations are so instructive and perfect that they can be used in future textbooks. The monograph considerably expands and enriches our knowledge of the spe- cies...”. In 2005 Elżbieta became extraordinary professor of Adam Mickiewicz University.

Professor Elżbieta Koralewska-Batura was a very universal malacologist, dealing not only with faunistics and anatomy; she was also the first to start studying gastropod communities of oak-hornbeam forests of Wielkopolska. She was an outstanding field biologist who collected all material herself. Her scientific production includes more than 40 publications. Elżbieta was one of the initiators of the series of monographs on gastropods, since 2000 published by the Kontekst Publishers. Very pedantic, despite her poor health in the last years, she arranged and catalogued her collection till the very last moment, and transferred it to the Natural History Collections, Faculty of Biology. She started curating the malacological materials accumulated by students during preparation of their diploma theses. This task she never managed to complete...

Fighting with the incurable disease, Elżbieta never for a moment stopped her scientific studies, field work and writing. When she died, many of these papers, though still not published, were completed or nearly completed. Her colleagues and co-authors of the papers decided to publish them. The series will appear in consecutive issues of Folia Malacologica, a specialist journal to which Elżbieta was emotionally attached from the very beginning.

Elżbieta supervised numerous bachelor's and master's theses, as well as one doctoral thesis. She was a member of the Poznań Scientific Society and the Association of Polish Malacologists. She was very a very unassuming person and a good friend, and we will remember her so.

Head and staff of the Department of General Zoology, Adam Mickiewicz University in Poznań 


\section{ELŻBIETA KORALEWSKA-BATURA - PUBLICATION LIST}

KORALEWSKA E. 1979. Ślimaki (Gastropoda) Ziemi Wrzesińskiej. Bad. Fizjogr. Pol. Zach., C - Zoologia 32: 105-113.

KORALEWSKA-BATURA E., STĘPCZAK K. 1980. Wdrażanie programu biologii powszechnej szkoły średniej w klasie IV. In: BOGDAŃSKA A. (ed.). Problemy metodologiczne eksperymentalnych badań programowych. WSZiP, Warszawa, pp. 95-97

KorALEWSKA-BATURA E. 1982. Plan lekcji biologii klasy IV szkoły podstawowej z działu "Higiena i zdrowie człowieka”. Biologia w Szkole, Warszawa 1(35/177): 42-43.

KORALEWSKA-BATURA E., STĘPCZAK K. 1983. Organizacja skupu winniczków oraz problemy ich przechowywania i transportu w punktach skupu i bazach eksportowych. Pr. Kom. Biol. PTPN, Warszawa-Poznań: 85-94.

KORALEWSKA-BATURA E. 1989. Ślimaki (Gastropoda) wybranego lasu grądowego Wielkopolski na przykładzie rezerwatu Jakubowo. Fragm. Faun. 32: 445-456.

KORALEWSKA-BATURA E. 1990. Budowa strzałki miłosnej u gatunków rodzaju Cepaea (Held) (Mollusca, Pulmonata). Przegl. Zool. 35: 391-393.

KorAlewSKA-BATURA E. 1992. Mięczaki (Mollusca) Wielkopolski. Wyd. Nauk. UAM Poznań, Ser. Zool. 18: 1-41.

KORALEWSKA-BATURA E., DZIABASZEWSKI W. 1992. Mięczaki (Mollusca) łęgów rogalińskich. Morena. Wielkopolski Park Narodowy, człowiek i środowisko - wybrane problemy l: 42-43

KORALEWSKA-BATURA E. 1993. Nowe dane o występowaniu Helix lutescens Rossmässler, 1837 (Gastropoda: Pulmonata) w Polsce. Przegl. Zool. 37: 69-72.

KorALEWSKA-BATURA E. 1993. Ślimaki (Gastropoda) siedlisk gradowych pod Opalenicą (woj. poznańskie). Bad. Fizjogr. Pol. Zach., C - Zoologia 39: 49-63.

KORALEWSKA-BATURA E. 1993. Lądowa fauna mięczaków (Mollusca) Wielkopolski. Bad. Fizjogr. Pol. Zach., C Zoologia 40: 5-13.

KORALEWSKA-BATURA E. 1993. Charakterystyka biometryczna skorupki ślimaka żółtawego (Helix lutescens Rossm.) w Polsce. Przegl. Zool. 37: 283-289.

KORALEWSKA-BATURA E. 1993. Die Struktur der Liebespfeile der Gattung Helix Linnaeus (Gastropoda:Pulmonata: Helicidae). Folia Malacol. 5: 115-118.

JaCKiEWicz M., BŁoszyK J., KoralewSKa-Batura E. 1993. Die Nacktschnecken der rischen Kiefemwalder (Leucobryo - Pinetum und Peucedano - Pinetum) auf dem Gebiet Polens (Gastropoda: Pulmonata). Malak. Abh. 16: 213-220.

KORALEWSKA-BATURA E. 1994. Development of reproductive organs of Helix lutescens Rossm. (Gastropoda, Pulmonata). Biol. Bull. Poznań 31: 67-70.

KoRALEWSKA-BATURA E. 1994. Bau der Radula bei einigen Arten der Familie Helicidae aus Polen (Gastropoda: Pulmonata). Biol. Bull. Poznań 31: 71-82.

JACKIEWICZ M., KORALEWSKA-BATURA E. 1995. The shell surface sculpture of Lymnaeidae (Gastropoda: Pulmonata: Basommatophora). Malak. Abh. 17: 191-198.

JACKIEWICZ M., KORALEWSKA-BATURA E. 1995. The shell surface sculpture of Succineidae (Gastropoda, Pulmonata: Stylommatophora). Biol. Bull. Poznań 32: 103-105.
STĘPCZAK K., KoralewSKa-BATURA E., LeŚNIEWSKA M., STĘPCZAK G. 1996. Program nauczania w klasach IV-VIII szkoły podstawowej "Biologia z higieną i ochroną przyrody". Zatwierdzony do użytku szkolnego przez MEN w dniu 3. 07. 1996 r. nr decyzji DKO 4014-3/96. WSZiP, Warszawa, pp. 1-20.

KORALEWSKA-BATURA E. 1997. Sinistrally coiled specimen of Helix lutescens Rossmässler, 1837 (Gastropoda: Stylommatophora: Helicidae). Malak. Abh. 18: 233-237.

KORALEWSKA-BATURA E. 1997. Analysis of lung haemal system in Helix lutescens Rossm. (Gastropoda, Pulmonata). Bioll. Bull. Poznań 34: 69-72.

KORALEWSKA-BATURA E. 1998. Ślimaki lądowe (Gastropoda terrestria) wysp leśnych. In: BANASZAK J. (ed.). Ekologia wysp leśnych. Wyd. WSP, Bydgoszcz, pp. 81-84.

JaCKieWicZ M., KoralewSKa-BatURa E., Lesicki A. 1998. Anomalies of soft body parts in Acicula polita (Hartmann, 1840), Deroceras laeve (O.F. Müller, 1774) and Deroceras reticulatum (O.F. Müller, 1774) (Mollusca, Gastropoda). Biol. Bull. Poznań 35: 39-42.

KORALEWSKa-BATURA E. 1999. Helix lutescens Rossmässler, 1837 (Gastropoda: Pulmonata: Helicidae) - its structure, biology and ecology. Folia Malacol. 7: 197-240.

JaCkiewicz M., Koralewska-Batura E. 1999. Pneumostome structure in Helix pomatia Linnaeus, 1758 and $H$. lutescens Rossmässler, 1837 (Gastropoda: Pulmonata; Helicidae) - another diagnostic character. Folia Malacol. 7: 43-45.

JACKIEWICZ M., KorAlEWSKA-BATURA E., LESICKI A. 1999. Shell anomalies and regenerations in some snail species (Gastropoda: Pulmonata). Malak. Abh. 19: 257-264.

KoralewSKA-BATURA E., DZiABASZEWSKI A. 2000. New localities of Cepaea vindobonensis Ferussac, 1821) (Gastropoda: Pulmonata: Helicidae) in Wielkopolska (W Poland). Folia Malacol. 8: 229-231.

KORALEWSKA-BATURA E. 2000. Terrestrial gastropods. In: BANASZAK J. (ed.) Ecology of forest islands. Bydgoszcz University Press, pp. 79-82.

TRYJANOWSKi P., KoRALEWSKA-BATURA E. 2000. Inter-habitat shell morphometric differentation of the snail Helix lutescens Rossm. (Gastropoda: Pulmonata). Ekologia (Bratislava) 19: 111-116.

JACKIEWICZ M., KoralewSKA-BATURA E. 2000. Columella structure in some snail species (Gastropoda: Pulmonata). Folia Malacol. 8: 223-227.

KORALEWSKA-BATURA E. 2002. Winniczek i jego krewniacy. In: WIESIOŁOWSKI J. (ed.) Wśród zwierząt i roślin. Wyd. Miejskie, Kronika Miasta Poznania, Poznań, pp. 91-100.

KORALEWSKA-BATURA E. 2002. Ślimak żółtawy (Helix lutescens Rossm.). Budowa, biologia ekologia i występowanie w Polsce. Wyd. Kontekst, Poznań.

ChOlewa S., Koralewska-Batura E., BATURA M. 2003. A new locality of Monacha cartusiana (O. F. Müller, 1774) (Gastropoda: Pulmonata: Helicidae) in Poland. Folia Malacol. 11: 59-61.

KoralewSKa-BatURA E. 2004. Helix lutescens Rossmässler, 1837 Ślimak żółtawy. In: GŁOWACIŃSKI Z. (ed.). Polska 
czerwona księga zwierząt. Bezkręgowce. PWRL Warszawa, pp. 341-342.

BŁoszyK J., Dylewska M., GoŁdyn B., Konwerski Sz., KoRALEWSKA-BATURA E., KUPCZYK M., LEŚNIEWSKA M., NAPIERAŁA A., ZIOMEK J. 2005. Świat zwierząt. In: GOŁDYN R., JACKOWIAK B., BŁOSZYK J. (eds). Walory przyrodnicze doliny Cybiny i ich ochrona. Wyd. Kontekst, Poznań, pp. 44-51.

LEŚNIEWSKA M., KORALEWSKA-BATURA E., BŁOSZYK J. 2005. Centipede communities in oak-hornbeam forests of different ages and exploitation in Wielkopolska (Poland). Peckiana 4: 69-79.

SZYBIAK K., KoralewSKa-BATURA E., GOŁDYN B. 2005. Quantitative studies of terrestrial gastropods of the Drawa National Park. Folia Malacol. 13: 35-42.

LESiCKI A., KorAlewSKA-BATURA E. 2007. Monacha cartusiana (O. F. Müller, 1774) (Gastropoda: Pulmonata: Hydromiidae) becomes more frequent in Poland. Folia Malacol. 15: 181-184.

SZYBIAK K., BŁOSZYK J., KORALEWSKA-BATURA E., GOŁDYN B. 2009. Small-scale distribution of wintering terrestrial snails in forest site - relation to habitat conditions. Pol. J. Ecol. 57: 377-388.

SZYBIAK K., BŁosZYK J., KORALEWSKa-BATURA E., GOŁDYN B. 2009. Variation in spatial structure and abundance of clausillids (Mollusca: Clausiliidae) in the nature reserve Dębno nad Wartą (W. Poland) during wintering. J. Conch. 39: 611-620.

KoralewSKa-BATURA E., BŁoszyK J., NAPiera€A A., GOŁDYN B. 2010. Biodiversity of terrestrial malacocoenoses as a criterion in Assessment of conservation status - the Cybina Valley, A proposed Natura 2000 area. Folia Malacol. 18: 5-13.

KoraleWSKa-BATURA E., BŁosZYK J., GOŁDYN B., SZYBiaK K., LESICKI A., NAPIERAŁA A. 2010. Materials to the knowledge of molluscs of Wielkopolska. I. History and general remarks. Folia Malacol. 18: 15-28.

KORALEWSKa-BATURA E., GOŁDYN B., SZYBIAK K., BŁOSZYK J. 2010. Materials to the knowledge of molluscs of Wielkopolska. II. Checklist. Folia Malacol. 18: 29-41. 